\title{
Casamento Tradicional
}

\author{
Morto Baiém Fandé \\ Universidade Severino Sombra, Centro de Ciências \\ Exatas Tecnológicas e da Natureza, \\ mortobaiemfande@yahoo.com.br
}

Fatumata é o meu nome. Tenho 13 anos e nasci na Guiné-Bissau, zona de Quinara. Há 2 anos passei o primeiro ritual de entrada na idade adulta. Como todas nós, meninas da minha idade, em breve casar-me-ei com um homem escolhido para mim desde que abri os olhos para o mundo que me rodeia.

Amo a minha terra, a minha gente e respeito toda a tradição que conheço. Por isso, ao ver aproximar a altura em que serei obrigada a casar com um homem mais velho do que eu 39 anos, que mal vejo, começo a por em causa tudo o que conheço. Sinto um aperto.Penso no meu futuro ao de um homem por quem nada sinto.

É o momento de maior tristeza que conheço na minha vida. Noites e dias passo sem sono, sem comer, às vezes comendo uma vez por dia. A situação conduziu-me a refletir profundamente sobre a tradução balanta, a minha etnia, e a condenar tudo o que diz respeito ao casamento das meninas com idade menor e a proibição de opinião a estas quanto à escolha do marido.

Mas, é uma prática enraizada, secular ou milenar, difícil de ser combatida e de ser abandonada pelo balanta. Então o maior problema que me circula pela memória seria o de encontrar um caminho que me pudesse livrar do compromisso assumido pelos meus pais e tios que, há sete anos, consomem, anualmente, sem o meu consentimento, o vinho de um homem que pretende casar comigo. Uma solução aparece-me à vista, conversar com a minha mãe que, apesar de tradicionalmente não ter nenhum poder de alterar a situação, mesmo que seja contra a sua vontade, poderá ajudar-me com alguns conselhos. Ao meu pai não fazia sentido. Além de ser um dos mentores, sabe-se que o homem balanta relaciona-se pouco com as filhas, em particular com as que ainda não se casaram.

O homem balanta não decide quanto ao casamento das próprias filhas, sob pena de ser entendido como orgulhoso e as filhas a serem perseguidas em feitiçaria. São os irmãos dele os maiores decisores sobre o assunto.

Numa manhã, aproveitando a ida do meu pai ao mato, eu e a mãe conversamos:

Mãe, achas que devo casar com um homem daquela idade?

Fatumata, sabes que a minha opinião quanto a essa prática é como a de um cachorro. A nossa tradição confere todos os poderes ao homem; neste caso é ao teu pai aos e irmãos dele que temos de obedecer. Qualquer opinião minha será mal acolhida e serei tomada como quem te instiga a rejeitar o homem que escolheram para ti. Podem em reação datar o casamento num curto tempo possível. Também uma opinião tua contrária a deles levarte-ia a uma forte tortura.

Obrigada, mãe! Tenho que fugir deixando esta aldeia, Tchintchidari, onde nasci e vivi, para viver noutra terra de que ainda não sei nem o caminho, nem o nome. Pois, a essa situação não posso conformar-me. 
Não fujas, filha, casa-te! No inicio é sempre dor, mas tudo há-de passar.

A minha mãe discorda da eventual fuga, entendendo que poderá ser fatal ao meu futuro. Pois, no balanta a recusa por parte da filha ao marido escolhido pelos pais é dada como uma autentica humilhação a esses. Esse fato conduz, normalmente, o recurso do pai ao seu Ir $\tilde{a}^{l}$, onde nu, fazendo alguns gestos, derrama a água, pedindo que a filha desobediente não possa ter filhos. Até porque, às vezes, o pai declara, perante familiares e outros, que a filha desobediente não serve de nada para ninguém e autoriza que qualquer familiar que queira e possa fazer dela algo em feitiçaria, que o faça.

No entanto, passaram-se duas semanas para que, numa madrugada, o meu pai me chame a informar que será trazido, brevemente, o último vinho, depois do qual deveria, segundo costume, ir junto ao futuro marido, pelo menos dois meses, para ter amizade com ele e os seus familiares, regressando algum tempo antes da cerimônia de casamento. É nesta madrugada que começam as cenas que resultaram na minha tortura. $\mathrm{O}$ meu pai e eu não nos entendemos. Resmungando, fiz-lhe saber que não gostava nem de pisar a varanda do dito noivo, que fará casar com ele. E pai com o seu grito:

_ Ah! És dona de ti para nos envergonhar perante o nosso amigo? Tu estás...

E eu ainda:

_ Não vou me casar com um homem que não conheço. Ainda velhíssimo!

Então, descontente comigo, logo de manhã chamou os seus e os meus irmãos mais velhos que, como ele, acharam o meu comportamento um atrevimento. Imediatamente, os meus irmãos receberam a ordem para me amarar as mãos e os pés. A isso seguiram-se pancadarias e ameaças para, finalmente, ser abandonada ao sol durante muitas horas. A minha libertação só veio a acontecer poucos minutos depois de ouvir a voz da minha mãe, logo calada pelos gritos, dizendo:

- Perdoem-na.

- O acontecido custou-me cinco dias de permanência sobra a cama e a data do casamento marcada para dali a quarenta dias.

Indo à fonte, numa tarde, à procura da água, ali veio encontrar-me a Binhambitida, a minha amiga que, há mais de três anos, vive em Bissau. Após cumprimentos, tudo o que seguidamente falamos parece ser motivado pelo meu estado físico.

Fatumata! És tu!? O que é que se passa contigo?

- Nada.

_ Nada! Não. O teu corpo mostra que algo está a se passar contigo. Conta-me!

_ É o problema habitual com que todas nós nos deparamos nesta idade, o do casamento.

_ Eu... não quero o homem, um velho, que escolheram para mim.

A conversa foi longa e pormenorizada. Entretanto, é nesta amiga de sempre que encontro a possibilidade de me libertar da opressão. Sugeriu que fugisse com ela no dia do seu regresso, três dias depois, para Bissau. A sugestão dada coincidiu com a idéia que tinha há quase dois meses e que não se concretizou por falta de local e pessoa a que/m pudesse recorrer. 
Já que é assim, concentramo-nos logo a estudar a possibilidade de viajarmos sem que a amiga e sua família fossem responsabilizadas da minha fuga. Concluímos que devamos viajar sem sermos vistas juntos por qualquer pessoa da aldeia. Assim, combinamos que a Binhambitida partiria um dia antes para a casa do tio em Buba, capital da região, e cidade mais próxima, e eu um dia depois, para nos encontrarmos na paragem, às 11 horas, e seguirmos para Bissau.

Ao ir para Buba, conforme o combinado, Binhambitida despediu-se de todos, inclusive dos meus pais, dizendo que voltaria nesse dia para Bissau. Eu, fingindo nada saber, é no quintal que fui passar toda a manhã, sem apontar os olhos na frente para ver a amiga e me despedir dela.

No dia da minha vez de partir, acordei cedinho para varrer a casa e encher o pote. Os meus pais, sem desconfiança, seguiram, às 8 horas, o caminho para o arrozal. Nessa hora aproveitei a saida. Com a minha pasta nas mãos, pus-me a correr, a caminho de Buba. Ali, na paragem, de longe, vi a Binhambitida e soltei a voz de alivio.

_ Binhambitida, cheguei!

Sem muita conversa, entramos rapidamente num condonga ${ }^{2}$ rumo a Bissau, onde agora tento retomar a vida normal, apesar da notícia de que o meu pai já sabe onde estou.

Bissau, 31 de março de 2008.

\section{Notas}

1 Designação genérica de deus, protetor e castigador; espírito que aparece normalmente sob a forma de serpente mas que assume outras formas. Guiné- Bissau

2 Carro de transporte comum (Guiné-Bissau) 